\title{
Penyakit dalam Perspektif Ihsan
}

Oleh: YUSH-NAWWIR

yushnawwir@gmail.com

Ketika seorang muslim ditimpa penyakit, maka yang pertama dilakukan adalah membangun kesadaran bahwa apa yang menimpanya adalah bagian dari kasih sayang Allah yang termanifestasi dalam bentuk penyakit dalam pandangan manusia. Apa yang menimpa manusia berupa penyakit pada hakekatnya bukanlah sesuatu yang negatif sehingga ia diposisikan sebagai musuh, tetapi sesuatu yang dapat memberi manfaat yang sangat besar pada diri manusia sebagai hamba Allah. Untuk mencapai semua ini, seorang yang sakit harus mampu bersabar agar ia mampu menepis segala hal-hal yang bisa merusak kesabarannya.

Kata Kunci: sakit; ihsan

\section{PENDAHULUAN}

Pada dimensi ihsan atau spritual, ${ }^{1}$ gaya hidup hedonisme dalam genggaman industrialisasi telah melahirkan manusia ibarat robot yang bekerja terus-menerus memenuhi target pencapaian material guna meraih keuntungan yang besar, telah menyeret manusia ke Hubb al-Dunyā wa Karāhiyah al-Maūt, ${ }^{2}$ jauh dari sifat zuhud, menjadi serakah, adalah penyebab korupsi merajalela dalam setiap lini kehidupan. Kondisi ini melahirkan ragam penyakit yang multidimensi dan menjadi sebuah epidemi yang membutuhkan waktu lama untuk menyembuhkannya. Dalam al-Qur'an, penyakit ini termanifestasi dalam sikapsikap Fir'aun dan antek-anteknya. Salah satu sikap yang sangat mencolok adalah apa yang dilakoni oleh Karun dengan segala gaya hidup yang mengitarinya.

Memaknai penyakit dari aspek filosofis adalah di luar domain ilmu kedokteran. Para dokter tidak lagi perlu mengetahui aspek-aspek yang bermanfaat dan makna potensial suatu penyakit. Kematian sebagai isu eksistensial akhir pada tataran filosofis senantiasa dihindari oleh para dokter bahkan bersifat inkar mati. Perbedaan antara kematian yang baik dan kematian yang buruk tidak ada artinya; kematian menjadi sekedar diamnya mesin tubuh secara total. Sedang dalam ajaran islam, kematian yang baik/husn al-khätimah merupakan prioritas utama setiap muslim. Setiap muslim yang sedang berada di sisi seorang muslim lainnya yang sedang menghadapi sakarāt al- maut, dia harus menuntunnya menuju ke kematian yang baik/ḥusn al-khätimah.arus menuntunnya menuju ke kematian yang baik/ḥusn al-khätimah.

\section{PEMBAHASAN}

${ }^{1}$ Spritual berarti ikatan yang lebih bersifat kerohanian atau kejiwaan dibandingkan hal yang bersifat fisik atau material. Ia merupakan kebangkitan atau pencernaan diri dalam mencapai makna hidup dan tujuan hidup dan merupakan bagian esensial dari keseluruhan kesehatan dan kesejahteraan seseorang. Lihat Tamami, Psikologi Tasawuf, h. 19

${ }^{2}$ Ini adalah penggalan hadis Nabi Saw. Lebih lanjut, lihat Abū Dāwūd al-Sajastāni, Sunan $A b \bar{u}$ Dāwūd kitab al-Malāhim, (Cet. II; Riyāḍ: Maktabah al-Ma‘ārif, 1424 H.), h. 769 


\section{A. Sakit adalah Jalan Menuju Surga}

Ketika seorang muslim ditimpa penyakit, maka yang pertama dilakukan adalah membangun kesadaran bahwa apa yang menimpanya adalah bagian dari kasih sayang Allah yang termanifestasi dalam bentuk penyakit dalam pandangan manusia. Apa yang menimpa manusia berupa penyakit pada hakekatnya bukanlah sesuatu yang negatif sehingga ia diposisikan sebagai musuh, tetapi sesuatu yang dapat memberi manfaat yang sangat besar pada diri manusia sebagai hamba Allah. Untuk mencapai semua ini, seorang yang sakit harus mampu bersabar agar ia mampu menepis segala hal-hal yang bisa merusak kesabarannya. Seorang yang sabar akan memeroleh janji Allah swt berupa surga sebagaimana firman Allah swt dalam QS al-Insān/76:12;

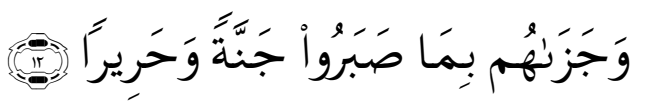

Terjemahnya:

Dan Dia memberi balasan kepada mereka karena kesabarannya (berupa) surga dan (pakaian) sutera. ${ }^{3}$

Menurut al-Qāsimi, kesabaran yang dimaksud dalam ayat di atas adalah kesabaran dalam ketaatan dan menjauhi larangannya, mengajak ke jalan Allah, dan bersabar menghadapi gangguan dan penderitaan. ${ }^{4}$ Penyakit merupakan sesuatu yang sangat mengganggu kehidupan manusia yang dijalani dengan penuh penderitaan.

Keutamaan orang yang sakit merupakan penghargaan tersendiri bagi seorang muslim dari Allah swt. karena mendapat keistimewaan berupa pengampunan kesalahan sebagaimana dalam hadis Nabi yang mengatakan;

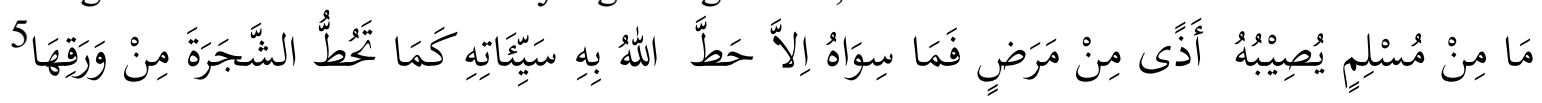

Terjemahnya:

Setiap muslim yang ditimpa musibah seperti penyakit atau lainnya, maka Allah menghapus kesalahannya laksana pohon yang berguguran daunnya.

Hadis ini sudah cukup bagi seorang muslim dalam membangun keyakinannya bahwa adanya penyakit yang menimpa dirinya adalah sebuah penghargaan dari Allah swt. Oleh karena itu, orang yang sakit adalah orang yang telah dipilih oleh Allah swt.untuk digugurkan dosa-dosanya. Dalam kehidupan sehari-hari, tampak banyak orang melakukan sesuatu yang menurut pandangan manusia sudah seharusnya sakit karena kelalaian menjaga kesehatan, namun tidak dipilih oleh Allah sebagai orang yang memeroleh pahala besar. Pada sisi lain, ada orang yang sangat ketat menjaga kesehatannya, namun ia terpilih menjadi hamba yang akan digugurkan dosanya dengan cara mendapat penyakit.

Dengan besarnya pahala bagi orang sakit, maka tidak berlebihan kalau dikatakan bahwa sakit adalah jalan menuju surga. Ketika seseorang ditimpa penyakit, lalu diterima dengan penuh rasa syukur, sabar, berserah diri, tawakkal, rida, senatiasa berdo'a, berprasangka baik kepada Allah dan seterusnya, maka seluruh sifat-sifat terpuji tersebut yang menyatu pada diri orang sakit, akan mendapat pahala dari Allah swt. Lebih dari itu, Rasulullah saw. bersabda:

${ }^{1}$ Kementerian Agama RI, Al-Qur 'an dan Terjemahnya, h. 579

${ }^{2}$ Muḥammad Jamāl al-Dìn al-Qāsimì, Mahāsin al-Ta'wīl(Cet. I, jilid 16, t. tp, 1965), h. 6013

3Abū Husain Muslim bin Ḥajjāj al-Naisabūri, Sahịh Muslim, (Cet. I, Jilid II, Riyad: Dār Taybah, 2006), h. 1196 no hadis: 2571 
Terjemahnya:

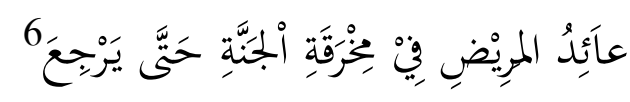

Orang yang menjenguk orang sakit sentiasa berada dalam taman surga hingga ia pulang kembali.

Salah satu pengertiannya yakni ia berada pada jalan menuju surga karena itu menjenguk orang sakit merupakan fardu kifayah. ${ }^{7}$ Kalau menjenguk saja orang sakit, seseorang sudah berada di taman surga maka jelaslah bahwa orang sakit berada dalam surga.

\section{B. Istiqamah dalam Menambah Amal Kebaikan.}

Adanya penyakit yang menimpa seorang mukmin merupakan momentum yang sangat berharga bagi dirinya untuk senantiasa mendekatkan diri kepada Allah swt. Berbagai macam kalimah tayyibah yang dapat dijadikan zikir sepanjang waktu untuk mengundang datangnya rahmat Allah swt berupa kesembuhan. Allah berfirman dalam QS Fușṣilat/41:30;

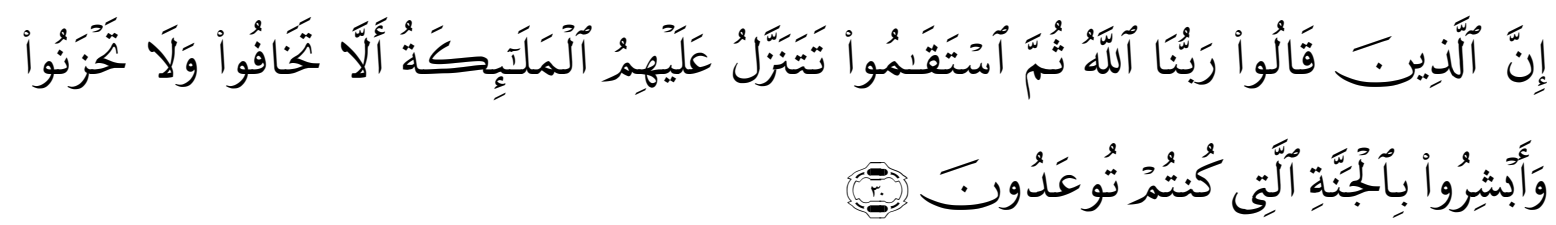

Terjemahnya:

Sesungguhnya orang-orang yang berkata, "Tuhan kami adalah Allah" kemudian mereka meneguhkan pendirian mereka, maka malaikat-malaikat akan turun kepada mereka (dengan berkata), "janganlah kamu merasa takut dan janganlah kamu bersedih hati; dan bergembiralah kamu dengan (memeroleh) surga yang telah dijanjikan kepadamu". 8

Ayat ini turun terkait dengan Abū Bakr ra ketika ia ditimpa berbagai macam musibah dan cobaan, namun keimanan beliau tidak bergeser sedikitpun. Beliaulah yang mengucapkan kalimat rabbunā Allāh/Tuhan kami adalah Allah, lalu ia pun senantiasa istiqamah dan tak terpengaruh berbagai macan cobaan yang menimpanya. ${ }^{9}$

Imam al-Rāzi mengomentari ayat di atas dengan mengatakan bahwa kesempurnaan itu meliputi tiga aspek yaitu yang tertinggi adalah kesempurnaan jiwa, yang pertengahan adalah kesempurnaan tubuh dan yang terendah adalah kesempurnaan aspek luar. Kesempurnaan jiwa meliputi dua aspek yaitu pengetahuan tentang keyakinan sepenuhnya dan pengetahuan tentang amal saleh. Kesempurnaan manusia dapat diraih melalui pengetahuan tentang hakekat al-haq itu sendiri dan pengetahuan tentang hakekat kebaikan agar terdorong melakukan kebaikan. Pangkal pengetahuan keyakinan adalah makrifatullah , dan inilah yang diisyaratkan penggalan pertama ayat di atas inna al-lażina qālù rabbuna Allāh/sesungguhnya orang-orang yang berkata, "Tuhan kami adalah Allah". Pangkal amal saleh adalah ketika manusia istiqamah di jalan tengah, tanpa condong ke kiri atau ke kanan,

${ }^{4}$ Abū Ḥusain Muslim bin Hẹjjāj al-Naisabūrì, Saḥịh Muslim, h. 1195, no hadis: 2568.

${ }^{5} \mathrm{Abū}$ al-Fạ̣l 'Iyāọ bin Mūsā bin 'Iyāụ, Ikmāl al-Mu'allim bi Fawāid Muslim (Cet. I, Jilid 8, Cairo:Dār al-Wafā, 1998), h. 37

${ }^{6}$ Kementerian Agama RI, Al-Qur 'an dan Terjemahnya, h. 480

${ }^{7}$ Fakhr al-Dìn al-Rāzì, al-Tafsìr al-Kabïr, juz 27, h. 122. 
dan inilah yang diisyaratkan penggalan kedua ayat di atas $\dot{s} u m m a ~ s t a q a \bar{a} \bar{u} /$ kemudian mereka meneguhkan pendirian mereka. ${ }^{10}$

Beliau kemudian menjelaskan bahwa ada dua bentuk istiqamah dalam ayat di atas yaitu istiqamah dalam keyakinan terhadap agama, tauhid dan makrifah dan kedua adalah istiqamah mengerjakan amal saleh. ${ }^{11}$ Dalam kaitannya dengan seseorang yang ditimpa penyakit; maka ia harus senantiasa memelihara dua bentuk istiqamah ini dengan menghindari berbagai macam kemusyrikan yang biasa menghampiri orang sakit seperti praktek perdukunan dan semacamnya, juga senantiasa berbuat kebaikan semaksimalnya sebagaimana yang biasa ia lakukan ketika masih sehat.

Dengan cara seperti ini, maka penyakit yang menimpa seseorang akan melumpuhkan orang tersebut untuk berbuat dosa. Sebaliknya, ia hanya akan berbuat kebaikan semata. Dalam salah satu hadis Nabi saw. beliau bersabda:

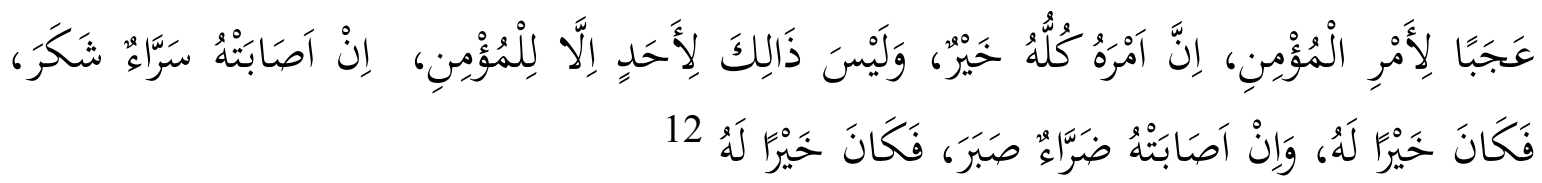

Terjemahnya:

Sungguh menakjubkan perkara seorang mukmin, semuanya bernilai kebaikan, dan hal ini hanya terjadi bagi seorang mukmin. Jika ia memeroleh nikmat, maka ia bersyukur dan itu lebih baik baginya, dan jika ia ditimpa musibah lalu bersabar, maka itu lebih baik baginya.

Salah satu hal penting yang harus dilakukan seorang yang ditimpa penyakit adalah senantiasa mendekatkan diri kepada Allah swt. melalui ibadah dan zikir. Hadis di atas menggarisbawahi dua sifat seorang mukmin yaitu syukur dan sabar. Syukur akan menjadikan orang mukmin senantiasa dalam ladang pahala karena kesyukuran menghilangkan kesusahan dan kesedihan. Seseorang yang senantiasa bersyukur akan selalu memuji Allah swt. Adapun kesabaran, adalah sifat para Nabi yang sentiasa diuji imannya oleh Allah swt. Kesabaran seorang mukmin akan berbuah rahmat dan kesuksesan. Sabar menerima penyakit sebagai anugrah dari Allah swt. patut disyukuri karena dalam keadaan sakit, banyak waktu luang dan kesempatan yang dapat digunakan untuk beribadah. Upaya mengambil hikmah dari setiap cobaan yang menimpa, adalah gambaran kesyukuran dan kesabaran seorang hamba. Syukur dan sabar bukan berarti pasrah di tempat tidur menunggu ajal menjemput, akan tetapi berusaha memaknai cobaan dan ujian tersebut dengan meningkatkan ibadah dan mendekatkan diri kepada-Nya. Dalam hadis lain, Rasulullah saw bersabda:

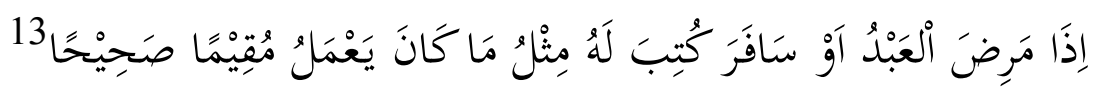

Terjemahnya:

${ }^{8}$ Fakhr al-Dīn al-Rāzì, al-Tafsir al-Kabïr, juz 27, h. 123.

${ }^{9}$ Fakhr al-Dìn al-Rāzìi, al-Tafsìr al-Kabìi, juz 27, h. 123.

${ }^{10}$ Abū Ḥusain Muslim Bin Ḥajjāj al-Naisabūrì, Saḥịh Muslim, h. 1365, no hadis: 2999.

${ }^{11} \mathrm{Abū}$ 'Abdillah Muhammad bin Ismā‘îl al-Bukhārȳ, al-Jāmi ' al-Ṣaḥịh (Cet. I, Jilid 2, Cairo: 1400 H), h. 237, no hadis 2996. 
Jika seorang hamba sakit atau safar, maka akan ditulis untuknya seperti apa yang biasa ia kerjakan ketika menetap dan sehat.

Dalam riwayat lain disebutkan bahwa jika seorang hamba dalam perjalanan untuk suatu kebaikan atau ibadah lalu sakit, maka Allah memerintahkan malaikat pendampingnya agar menulis pahalanya sebagaimana ketika ia sehat hingga Allah memberinya kesembuhan atau membawa-Nya ke sisiNya (meninggal dunia). Seluruh amalan yang biasa dikerjakan ketika sehat, Allah senantiasa memberi pahala di saat sakit, bahkan dalam menunaikan salat fardu, Allah memberi pahala seakan menunaikan secara sempurna sebagaimana ketika sehat. ${ }^{14}$ Pernyataan ini menunjukkan betapa orang yang sakit mendapat keistimewaan dalam menambah amal kebaikannya.

\section{Menggapai Mati Syahid}

Mati syahid adalah cita-cita tertinggi seorang mukmin sebagaimana dalam sebuah slogan yang berbunyi al-mawtu fí sabīlillahi asmā amānīnā/mati di jalan Allah adalah puncak harapan kami. Namun demikian mati syahid adalah rahasia Allah swt sehingga seseorang tidak dapat membuat program agar nantinya ia memeroleh mati syahid. Dalam sejarah telah diketahui secara umum bagaimana kepahlawanan "Si Pedang Allah Yang Terhunus/saifulläh al-maslür' Khalid bin Walid, namun ia justru mati ditempat tidurnya.

Allah swt. berfirman dalam QS Āli 'Imrān/3:140;

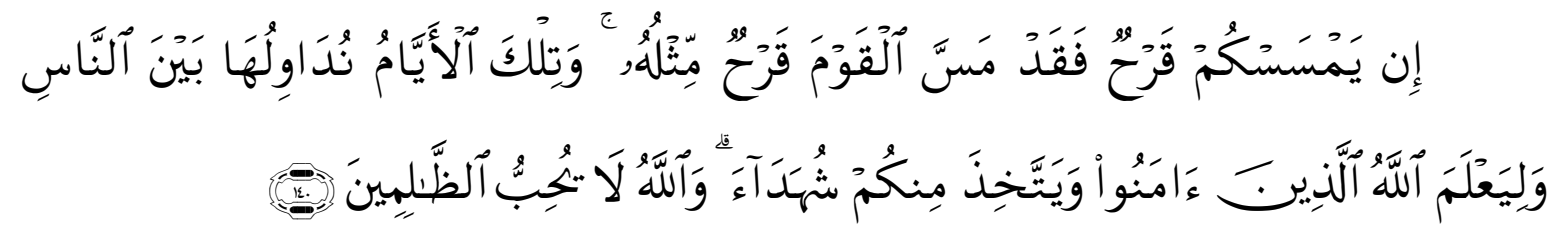

Terjemahnya:

Jika kamu (pada perang Uhud) mendapat luka, maka mereka pun (pada perang Badar) mendapat luka yang serupa. Dan masa (kejayaan dan kehancuran) itu, Kami pergilirkan di antara manusia (agar mereka mendapat pelajaran), dan agar Allah membedakan orang-orang yang beriman (dengan orang-orang kafir) dan agar sebagian kamu dijadikan-Nya (gugur sebagai) syuhada. Dan Allah tidak menyukai orang-orang zalim. ${ }^{15}$

Dalam konteks ini, Allah swt menceritakan peristiwa perang Uhud ketika kaum muslimin dikalahkan kaum musyrikin. Pada saat itu kaum muslimin sangat terpukul atas kekalahan tersebut karena salah satu penyebabnya adalah pasukan pemanah yang ditempatkan Rasulullah saw. di atas bukit meninggalkan tempat saat melihat pasukan yang lain mengumpulkan harta rampasan. Allah mengajarkan kepada mereka bahwa kalah dan menang adalah hal biasa dan kalian telah menang pada perang Badar yang terjadi sebelumnya.

Ayat di atas menunjukkan bahwa salah satu hikmah kekalahan kaum muslimin pada perang Uhud adalah Allah ingin mengangkat derajat orang-orang yang gugur dalam pertempuran ini sebagai syuhadaNya yakni orang-orang yang disaksikan karena keagungan,

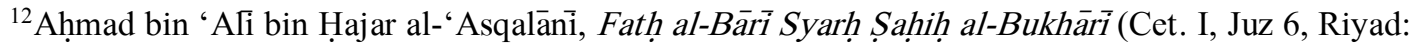
Maktabah al-Malik Fahd al-Wataniyah, 2001), h. 150

${ }^{13}$ Kementerian Agama RI, Al-Qur 'an dan Terjemahnya, h. 67
} 
keluhuran dan ketinggian akhlak melalui keteladanannya di tengah-tengah masyarakat termasuk termasuk pada hari kiamat; dan atau menjadi saksi-saksi kebenaran, yang menyaksikan apa yang diperbuat manusia, sambil membimbing, mengajar, menasehati serta memberi peringatan bagi mereka yang bersalah, dalam rangkaian menegakkan kebenaran dan mendapatkan keridaan Allah. ${ }^{16}$

Dengan demikian, Adanya penyakit yang menimpa seorang mukmin merupakan momentum yang sangat berharga bagi dirinya untuk senantiasa mendekatkan diri kepada Allah swt. Berbagai macam kalimah tayyibah yang dapat dijadikan zikir sepanjang waktu untuk mengundang datangnya rahmat Allah swt berupa kesembuhan. Karena itu, betapa agungnya Hamzah (paman Rasulullah), mati syahid dengan nama yang begitu mengharumkan. Penghargaan tersebut antara lain berupa dianugerahi rezeki terus-menerus oleh Allah (QS Āli 'Imrān/3:169) sesuai dengan nilai kejuangan mereka dan kebesaran serta kemurahan Allah, meskipun dari segi jasmani dan tolak ukur duniawi, maka mereka telah mati, namun hakekatnya mereka tetap hidup dengan kehidupan yang berbeda dengan di dunia ini, karena hidup mereka di sisi Tuhan yang Maha Agung. ${ }^{17}$

Allah juga memberi penghargaan sebagai mati syahid terhadap orang yang mati dalam keadaan sakit sebagaimana hadis Nabi saw yang menyatakan :

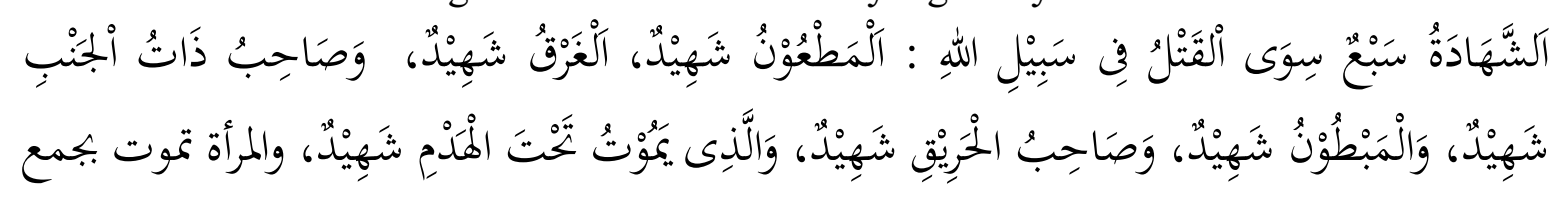

Terjemahnya:

Bahwa ada tujuh golongan orang yang dianggap sebagai mati syahid selain mati dalam peperangan fi sabilillah yaitu mati karena penyakit $t a$ ' $u n /$ kolera, mati karena tenggelam, mati karena penyakit zatuljanbi/radang selaput dada, mati karena sakit perut, mati karena kebakaran, mati karena ditimpa bangunan dan mati dalam keadaan hamil.

Hadis di atas menunjukkan Adanya penyakit yang menimpa seorang mukmin merupakan momentum yang sangat berharga bagi dirinya untuk senantiasa mendekatkan diri kepada Allah swt. Berbagai macam kalimah tayyibah yang dapat dijadikan zikir sepanjang waktu untuk mengundang datangnya rahmat Allah swt berupa kesembuhan. Namun demikian seseorang tidak dibolehkan meminta untuk mati, sebab cara ini merupakan gambaran keputusasaan seseorang dalam menghadapi cobaan hidup. Oleh karena itu, orang yang ditimpa penyakit harus selalu mengingat bahwa kehadiran sebuah penyakit pada diri seseorang bukan untuk mengantar orang tersebut ke gerbang kematian tetapi ia adalah manifestasi rahmat Allah swt. kepada dirinya.

\section{KESIMPULAN}

Berdasarkan pembahasan di atas, maka ditarik beberapa kesimpulan sebagai berikut:

${ }^{14}$ Mardan, Wawasan al-Qur'an tentang Malapetaka, cet. I, (Ciputat: Pustaka Arif, 2009), h. 255

${ }^{15}$ Mardan, Wawasan al-Qur'an tentang Malapetaka, cet. I, (Ciputat: Pustaka Arif, 2009), h. 256

${ }^{17}$ Abū Dāwūd Sulaimān ibn al-Asy'as al-Sajastānì, Sunan Abū Dāwūd, cet. II, (Riyad: Maktabah al-Ma'ārif, 1423 H), h.560, no hadis 3111 
1. Salah satu tujuan penyakit adalah menghapus dosa. Oleh karena itu, kehadirannya harus disyukuri dan dipelihara karena manfaatnya sangat besar pada diri manusia.

2. Adanya penyakit yang menimpa seorang mukmin merupakan momentum yang sangat berharga bagi dirinya untuk senantiasa mendekatkan diri kepada Allah swt. Berbagai macam kalimah tayyibah yang dapat dijadikan zikir sepanjang waktu untuk mengundang datangnya rahmat Allah swt berupa kesembuhan.

3. Penyakit adalah duta terbaik dari Allah swt karena membawa pintu mati syahid, sebagai sebuah pintu kematian yang sangat agung dan istimewa yang menjadi citacita tertinggi setiap muslim.

\section{KEPUSTAKAAN}

Kementerian Agama RI, Al-Qur 'an dan Terjemahnya

Muhammad bin Ibrāhīm bin 'Ubbād al-Randi. Syarḥ al-Hikam; juz I (Semarang: Karya Toha Putra, t.th.

Syaikh Hakim Mu'inuddin Chisyty, The Book of Sufi Healing diterjemahkan oleh Burhan Wirasubrata dengan judul Penyembuhan Cara Sufi, Jakarta: Lantera Basritama, 1999. Joe H. Slate, Aura Energy for Health, Healing and Balance, diterjemahkan oleh T. Hermaya dengan judul Energi Aura, memanfaatkan Energi Aura untuk Menjaga Kesehatan dan Keberhasilan Karir, (Cet. I, Jakarta: Gramedia Pustaka utama, 2002 Burhān al-Dīn Abi al-Ḥasan Ibrāhīm bin 'Umar al-Biqā'i, Naẓm al-Durar fì Tanāsubi alAyàt wa al-Suwar, Kairo: Dar al-Kitab al-Islami, t, th

Muhammad al-Amīn bin 'Abdullah al-Arūmī, Hadāiq al-Rūh wa al-Raiḥan, Beirut: Dar tawq al-najah, 2001

Al-Ṭāhir Ibnu 'Asyūr, al-Tahrīr wa al-Tanwir, Tunisiah: Dar al-Tunisiyah, 1984 Egha Zainur Ramadhani, Sehat\& Bugar Berobat dengan Alam, (Yogyakarta: Pro-U Media, 2012

Șubḥi Sulaimān, Nașāị Nabawiyyah li 'Ilāj al-Ajsād al-Basyariyah, Jerry D. Gray, Deadly Mist, Upaya Amerika Merusak Kesehatan Manusia, Fakhr al-Dīn al-Rāzì, al-Tafsìr al-Kabīr, juz 25, h. 29 